\title{
PRAEFATIO.
}

Tantum fuit Lessingri ingenium, tanta tamque praeclara extant eius, ut in omnes bonas literas, ita in artem criticam quoque, merita, quae vel posteritas Germanorum grata extollet laudibus, etiamsi lapideum tumulo eius nullum extet monumentum. Neminem sane elegantis doctrinae cupidum LESS ING I scripto- 
rum adeo ignarum esse puto, qui non hanc illamve eius criticam observationem legerit, mültaque admiratione plenus cognoverit, quam nccurate ingenium eius excellens versatum sit non modo in quaerendo de dubiorum et corruptortum locorum lectione, sed in examinandis quoque et sententiarum et orationis scriptorum virtutibus, diudicandisque aliorum coniecturis, suisque proferendis, iudicio denique interponendo idoneo atque gravi.

Quum vero tantus sit librorum I:essingri numerus, ut non facile 
emi a quovis possint, quumque cris ticae eius observationes passim in iis dispersae, adeoque non paucae earum exhibitae legantur iis libris, qui ab humaniorum literarum studiosis vel omnino non, vel raro tantummodo inspiciantur; non inutile iudicavi, excellentis Viri specimina critica in unum fisciculam colligere, quo facilius comparari, commodiusque perlustra:i a quovis possint.

Sed si quis miretur, cur hasce olsservationes in latinam linguam converterim; loc fictum nelitiquam 
cst eo consilio, ut Lessingri laboribus (quis enim hoc audeat?) doctiorem formam ac speciem imprimerem; imo graviores causae ad hoc me impulerunt consilium.

Nimirum Viri docti uno ore fatentur, Lessixgiva, omnium qui vernaculi lingua scripserunt, dignissimum esse, qui legatur a ṇationibus quoque nostram linguam non callentibus. Germanorum quidem tantum est studium, atiue tiantà laboris pertinacia, ut cupide addiscant Anglosaxonum, Francogallorum, Hetruscorum, linguas, ut 
quidquid ingenio atque doctrina excellens patrio illorum sermone prodeat, cognoscere possint. At non eadem studiorum ratio extat apud illos, quippe quum ob insanas difficultates, quarum plena est lingua Germanica, nostra contemnant. His igitur in primis tale munusculum afferre studui. Accedit, quod ipse Vossius, vir et honestissimus et elegantissimus, hoc mihi officii imposnit mihique significavit, sibi magis probari, si hanc Lessingro, qua eum prodire iussi, formam induerem. 


\section{* PraEfatio,}

Quod si iudicibus aequis ullo modo satisfecerim, humaniorumque literarum studiosis meo qualicunque labore gratum fecerim, vehementer laetabor. Scripsi Lipsiac, a. d, VI. Kal, Maias crorocclxxxxurr. 